\title{
Consensus Study on the State of the Humanities in South Africa:
}

Status, prospects and strategies Concise

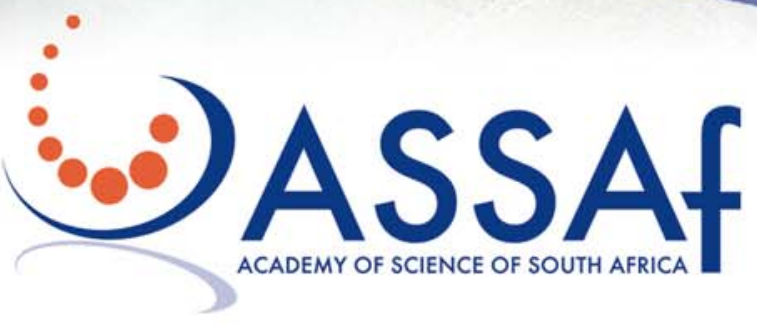


(C) Academy of Science of South Africa

August 201 I

ISBN- 978-0-98|4|59-3-2

Published by:

Academy of Science of South Africa (ASSAf)

PO Box 72135, Lynnwood Ridge, Pretoria, South Africa, 0040

Ist Floor Block A, The Woods, 4 I De Havilland Crescent, Persequor Park

Meiring Naudé Road, Lynnwood 0020, Pretoria, South Africa.

Tel: +27 I2 3496000 - Fax: +27865769520

E-mail:admin@assaf.org.za

Reproduction is permitted, provided the source and publisher are appropriately acknowledged.

The Academy of Science of South Africa (ASSAf) was inaugurated in May 1996 in the presence of President Nelson Mandela, the Patron of the launch of the Academy. It was formed in response to the need for an Academy of Science consonant with the dawn of democracy in South Africa: activist in its mission of using science for the benefit of society, with a mandate encompassing all fields of scientific enquiry in a seamless way, and including in its ranks the full diversity of South Africa's distinguished scientists. The Parliament of South Africa passed the Academy of Science of South Africa Act, Act 67 of 200 I, which came into operation on I5 May 2002. This has made ASSAf the official Academy of Science of South Africa, recognised by government and representing South

Africa in the international community of science academies. 


\section{Consensus Study on the State of the Humanities in South Africa: Status, prospects and strategies}

\section{Table of Contents}

Foreword

Introduction

The Case for the Huma nities

5

Where do the Humanities come from?

7

How did the Huma nities Change over Time?

9

How Productive a re the Humanities in Scholarship Terms? 11

Where do Huma nities Graduates go?

Main Findings

Ten Game-breaking Recommendations

17

Concluding Observations

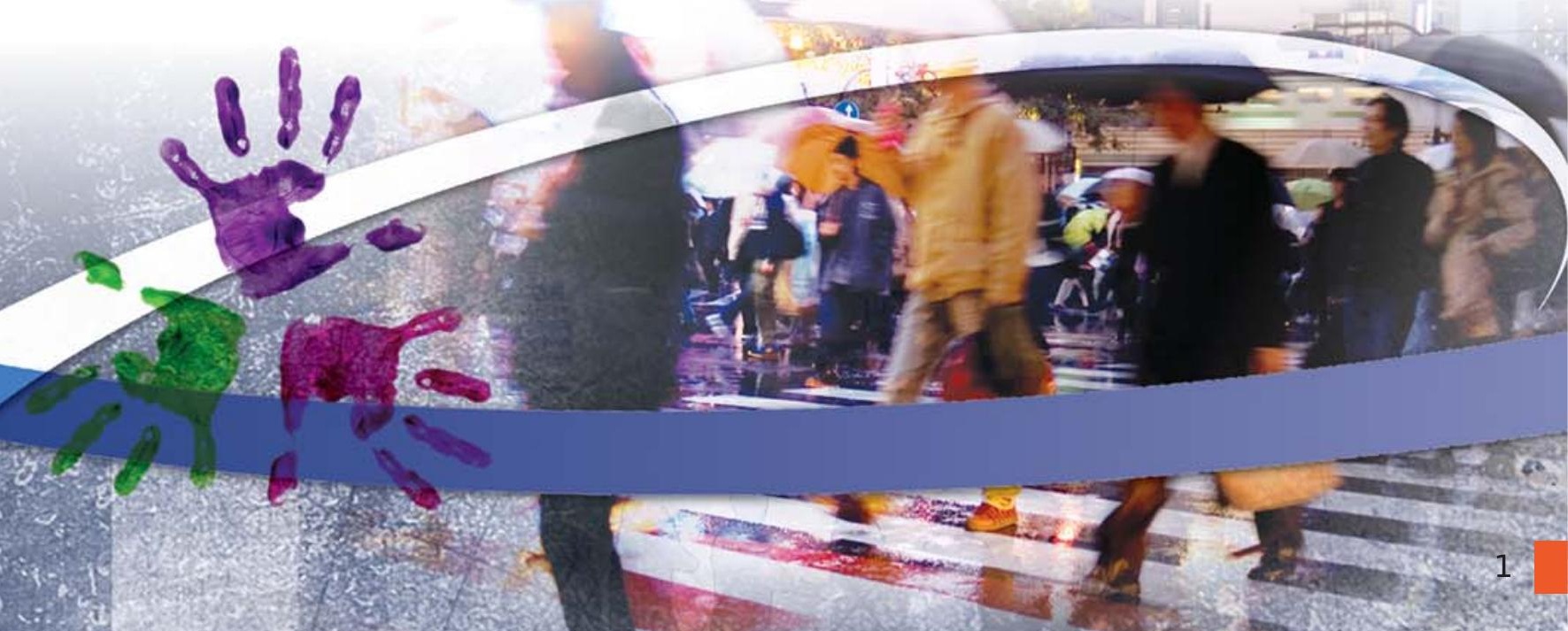




\section{Foreword}

The Academy of Science of South Africa is mandated to provide evidence-based advice to govemment on matters of crucial scientific importance; these evidence-based study project activities are at the core of the Academy's function and are a key area of future development. This Consensus Study on the Humanities is the twelfth in a series of this nature that the Academy has commissioned.

Asan independent body that holds the membership of many of the most prominent scientists in the country, the Academy is well placed to address questions of capacity within the national research system and is fortunate to be able to draw on a pool of committed expertise across universities and science-based organisations. Access to this resource proved invaluable in the production of this Report. The methodology used in the preparation of this, and other, reports of this kind is free of partisan interest. As a result, the findings and recommendations are the best possible considered outc omes in the circumstances.

This is the first-ever report on the Humanities in South Africa and, as is the custom, several interlinked studies were camied out to gather and collate both quantitative and qualitative data for it. The Report provides invaluable detail about the challenges and opportunities associated with tapping the many pools of excellence that exist in the country. It should be used as a guideline forpolic y-makers to do something concrete to improve the circumstances faced by the Humanities, not only in South Africa, but also a round the world.

The Report was developed and guided to its successful conclusion by a panel of experts, under the capable leadership of Professor J onathan J ansen and Professor Peter Vale. The members of the 'C onsensus Panel', as it wascalled and the authors of the variousconstituent study reports a re thanked for the care and attention they gave to their task.

\section{Professor Robin Crewe}

\section{President Academy of Science of South Africa}




\section{Introduction}

In many parts of the world concem has been expressed over the diminishing role which the Humanities are playing in the so-called 'knowledge chain'. Given these concerns, it is not surprising that in a number of countries - Ireland (Royal Irish Academy, 2007), the UK (British Academy, 2004), Germany (DFG, 2007), Switzerland (SWTR, 2006:25), and the Netherlands (Sustainable Humanities, 2009), to mention a few - initiatives and investigations have been launched into the Humanities, with recommendations on ways to both defend and rebuild them. The Panel's own encounters with different countries, in partic ular Australia, Bra zil, Egypt, Ghana and India, confirm that their experiences with the Humanities are closer to those of South Africa, and that they face a similar set of challenges.

As this Report was being written up, a blue ribbon panel was assembled by the American Academy of Arts and Sciences to look into similar issues. The following are some of their concerns: "you can't teach Math(s) and Science to people who can't read"; the goal of our work is "to maintain national excellence in Humanities and social scientific scholarship and education, and to achieve long-term national goals for our economic well-being; for a stronger, more vibrant civil society", and one which is more difficult to test but which all who know the Humanities recognise as true: "the Humanities...(are)... a treasure house of ideas" (Berrett: 2011). So, we can say that concem for the future of the Humanities is global, but the search for solutions is loc al.

Elsewhere in this country, a number of new initiatives on the Humanities have taken place. In August 2010, the Minister of Higher Educ ation and Training, DrBla de Nzima nde, a nnounced the formation of a Reference Group to develop what has been called a ' $C$ harter for the Humanities' - again the Humanities being broadly defined. The group is led by the distinguished University of Cape Town (UCT) Sociologist Professor Ari Sitas; the deputy chair is Dr Sarah Mosoetsa from the University of the Witwatersrand. The Department of Science and Technology (DST) has workshopped the 'Human and Social Dynamic in Development Grand Challenge Science Plan', which has opened the possibility both of additional fund ing for the Huma nities (broadly defined) and a widening of the scope for research in the Humanitiesa way from the applied end of the knowledge spectrum towards the more theoretical end. A few otherinitia tives are underway that might touch upon the Humanities in So uth Africa, an interesting one of which is the 'Frameworks for Africa-UK Research Collaboration in the Social Sciences and Humanities' (also called 'The Nairobi Process' after the city in which the first meeting took place), sponsored by the British Aca demy and the Association of Commonwealth Universities (ACU).

Taken individually, or together, these initia tives a re crucial for the future of the Humanities in South Africa and elsewhere. One of them a ims to influence policy and its making, i.e., the study put in motion by the Minister of Higher Education and Tra ining. We take this intervention to be sign of a deepening interest in the field by those charged with making policy. 


\section{Panel Members:}

\begin{tabular}{|ll|}
\hline Name & Afilliation \\
\hline Sakhela Buhlungu & University of Pretoria \\
\hline J ohn Higgins & University of Cape Town \\
\hline Catherine Odora Hoppers & University of South Africa \\
\hline J onathan Jansen & University of the Free State \\
\hline Sha mil J eppie & University of Cape Town \\
\hline Zne Magubane & Boston College \\
\hline Gerit Olivier & University of the Witwatersrand \\
\hline Deborah Posel & University of Cape Town \\
\hline Mpilo Pearl Sithole & University of KwaZulu-Natal \\
\hline Keyan Tomaselli & University of KwaZulu-Natal \\
\hline Peter Vale & University of J ohannesburg \\
\hline Andre van der Walt & University of Cape Town \\
\hline
\end{tabular}

\section{Chapters written by:}

\begin{tabular}{|c|c|c|}
\hline Name & Afiflation & Topic \\
\hline $\begin{array}{l}\text { Prof Peter Vale } \\
\text { Prof J ohn Higgins }\end{array}$ & $\begin{array}{l}\text { University of J ohannesburg } \\
\text { University of Cape Town }\end{array}$ & The Case for the Humanities \\
\hline Prof Mala Singh & Open University, UK & $\begin{array}{l}\text { Where do the Humanities come } \\
\text { from? }\end{array}$ \\
\hline Dr Lis Lange & University of the Free State & \\
\hline $\begin{array}{l}\text { Prof lan Bunting } \\
\text { (Emeritus) }\end{array}$ & University of Cape Town & $\begin{array}{l}\text { How did the Huma nities } \\
\text { Change over Time? }\end{array}$ \\
\hline Prof J ohan Mouton & Stellenb osch University & $\begin{array}{l}\text { How Produc tive are the } \\
\text { Humanities in Scholarship Terms? }\end{array}$ \\
\hline $\begin{array}{l}\text { Centre for Research } \\
\text { on Evaluation, Science } \\
\text { and Technology }\end{array}$ & Stellenbosch University & $\begin{array}{l}\text { Where do the Humanities } \\
\text { Graduates go? }\end{array}$ \\
\hline
\end{tabular}


Most human interaction begins - and ends - with communic ation. The imperative for communic ation amongst humans is linked to both the more practical world of the so-called 'hard' Sciences - Physic s, Chemistry, Biology, Medic ine - in a host of ways. Indeed, it is impossible to conceive of these Sciences without access to the knowledge that has been provided by the Humanities, just as access to Mathematics, the key to all the Sciences, is impossible without first accessing a spoken and written language. The Humanities not only observe and report on human communic ation, they are also charged with studying what it is that humans are communic ating and why they are doing so. At the hea rt of Huma nities lies the genius of critic al thought: the technique of asking deep-seated questions with the aim of gaining profound insights into the multiple challenges that face the human condition. This questioning spinit of the Humanities was responsible for the emergence of great political and social movements that have changed the world and set millions of people free. Critical approaches have also revealed social worlds that have lain hidden by the hold of orthodox thinking. In short, the Humanities provide socially centred responses to a n inc rea sing ly complex world.

The Humanitiesprovide both society and individua ls with a n informed sense of community and a common humanity. They promote intrinsic values that link understanding to ethical values. They explain why 'the other' is important, and create an understanding that a better world is possible. Training in the Humanities will be incomplete without the ability to read and understand a complex world, to weigh evidence and to communic ate opinions and findings clearly and succ inc tly. In this process, the ability to communic ate is of pa ramount importance. This begins and ends with the leamed facility to make clear and accessible arguments, and to read issues both within and beyond their context. Good Humanities graduates a re nonlinear thinkers who recognise that most questions have not one, but many, potential answers. They know that change is possible but recognise that both change and continuity in all fields a re laden with ethical dilemmas.

Appreciating the importance of the Humanities must begin with recognition that failure to acknowledge the complexity and dynamism of knowledge has been a feature of intellectual life for several decades. As a result, the importance of the Humanities has been badly misunderstood in the pursuit of the utilitarian outcomes of economic growth. Instead of build ing a community, this goal has a tomised soc iety and brought with it a series of problems, from global warming to poverty and pandemics, none of which can be managed or solved without input from community-centred perspectives championed by the Huma nities.

At the centre of our nation these seventeen years past has been the idea of Ubuntu: we are human because of other humans. The Humanities provide the glue of Ubuntu, and without them, our history tells us, we are a fractured and a fractiouspeople. This Report now returns to the idea of creating 'a people-centred society', and our preoccupation has been whether we can create that society if we fail to give attention to the Humanities, which has been at the centre of all that has previously divided, but now unites, South Africa's people. 


\section{Where do the Humanities come from?}

The a na lysis covers the two line ministries, sc ience and technology (S\&T) and highereducation $(\mathrm{HE})$, whose policies have direct c onsequences for the Humanities in terms of policy status and recognition in the domain of 'science' and research, availability of research funding and setting of research directions, and the production of skilled human resources. The predominant foc us has been on the S\&T department's polic ies and activities, given its politic al, symbolic and operational jurisdic tion over the different sc ience doma ins in the country and its alloc ation of place and value to the Humanities within its parameters for the scientific enterprise. The implic ations for the Huma nities of the polic ies and activities of other line departments have not been addressed, e.g., the departments where social science research may be und ertaken in support of line functions ${ }^{1}$.

Some of the key issues emerging from the analysis a re as follows:

- The analysis of science policy legislative and policy documents and their implications for and effects on the Humanities, indicates that in the unfolding trajectory of policy positions from the White Paper on S\&T (1996) to the DST's Ten-Year Plan (2009), the significance, contributory potential to development and full partner status of the Humanities have been given largely symbolic recognition only. This has not translated into more than handma idenly roles for the Huma nities within the National System of Innovation (NSI), nor into sophistic ated research fra meworks, which accommoda te different types of Huma nities research, nor into adequate levels of funding and support.

- The concept of innovation and the NSI, which is the foundation of science policy, is interpreted predominantly in relation to its 'techno-economic' signific ance. Advocacy for the Huma nities and making a case for the Humanities within the current science policy framework requires a simultaneous critical engagement with the prevailing conception of innovation and its implementation strategies.

- There may very well be commonalities of fate and fortune between the Humanities and the pure Natural Sciences in the science policy framework because of the narrowness of the notion of innovation and its privileging of applic ations-d riven resea rch. This could create the basis for collabora tive engagement, joint critiques and proposa ls for new a p proaches, ratherthan a ghettoising 'two cultures' approach or cla ims to Huma nities exceptionalism.

\footnotetext{
${ }^{1}$ An investigation, into which line departments' commission and use Humanities research, who undertakes such research, the nature, scale and volume of the research, and how and to what extent the research is used, may yield a useful indication of the possible contribution to and impact of Humanities research upon 'evidence-based' polic y-making in the country.
} 
- South African science policy indicates the influence of global paradigms for S\&T, with innovation cast as the driver of growth and development in the 'knowledge economy'. To what extent was this global paradigm mediated by the political project of social transformation in the country? A number of elements from the local context a re evident in the science policy discourse: the commitments from the Reconstruction and Development Programme (RDP) White Paper to democracy, equity and partic ipation; the emphasis on social inclusion in respect of the research and development (R\&D) strategy; a technology mission on poverty; the emphasis on indigenous knowledge systems (IKS); concern for the public understanding of science; and the reference to social innovation. A more substantial assessment of the global-local nexus in South African science policy and the resulting benefits for the local transformation a genda requires further analysis of the former Department of Arts, C ulture, Sc ience and Technology (DACST)/DST projects relating to the a bovementioned elements. However, a stronger and more central role for the Humanities may have ensured more substantial research and polic y attention to these elements from the transformation project in the country.

- The Humanities need champions and organisational spaces for advocacy and profile build ing. Other countries have dedic ated organisations which function as Humanities advocates engaging with govemment and other dec ision-ma kers, e.g. the British Aca demy in the United Kingdom. What possibilities are there within the Aca demy of Science of South Afric a (ASSAf), the National research Foundation(NRF), the Council on Higher Education (CHE), National Council on Innovation (NACI), the Human Sciences Research Council (HSRC), the disciplinary and professional associations, DST structures for the public understanding of science (e.g. the So uth Afric an Agency for Science and Technology Advancement (SAASTA), the National Science and Technology Forum (NSTF)) for championing the cause of the Humanities, including projects for increasing the public understanding of the Humanities? An added consideration is the question of how many senior staff within the DST or NRF have Humanities backgrounds to take up the Humanities cause within line department functions? It is also important to identify who a re likely to be the societal stakeholders of the Huma nities in the same way that Science, Eng ineering and Technology (SET) disciplines have business and industry as powerful stakeholders. What projects can be undertaken to 'create' such stakeholders? In this regard, what are the perceptions of students, pa rents, community organisations of the Huma nities as a field of employment and inc ome generation, as a source of $R \& D$ support, etc?

- Some non-Organisation for Economic Co-operation and Development (OECD) international reference points for Humanities advocacy, as well as benchmarking the role of Humanities in support of local development agendas, could include the Council for the Development of Social Science Research in Africa (CODESRIA), the Latin Americ an Counc il of Social Sciences (CLACSO), the Centre for the Study of Developing Societies in India (CSDS), etc.

- What is needed is a new imaginary framework for the Humanities, a positive re-invention of them in the face of new knowledge frontiers in all science domains. Academics and researchers in the Humanities have not always engaged critically with the fundamentals of the new science regime in the country, norbeen inwardly reflective enough on possible challenges to the Humanities from new research in science domains. Making a case for the Humanities in South Afric a may require, in the first instance, re-imagining the Humanities and their social positioning within knowledge production and application regimes in the country, looking to relevant examples in this regard in both OECD and non-OECD contexts. 
There is no question that scholars in the Huma nities fields benefit more from the DHET research subsidy scheme, as there are many more joumals in these fields - compared to the numbers of journals in the Natural and Health Sciences - included in the list of accredited journals of the DHET. The effect of this reality is most clearly illustrated in the relatively high output of two fields (Religion and Law), which together have more than 45 jouma ls recognised by the DHET. This does, of course, raise the question of the quality of some (especially the smaller) joumals, which has prompted ASSAf and subsequently the DHETto start with a regular review of all local joumals in 2009.

Asfar as shifts in modes of knowledge production are concemed, it is clear that new spaces for the Huma nities have opened up and will continue to do so. Mode 2 production of knowledge is alive and well in South Afric a in the form of social research consultancies (especially monitoring and evaluation, organisational development, strategic management, market research and policy studies).

However, this does not mean that there are no rema ining challenges for the Huma nities fields. The visibility of South Afric an sc hola rship needs further improvement. The c urrent trends towa rds increased collaboration and intemationalisation need to be sustained and expanded. The demographic s of the Humanities workforce is as 'fragile' as it is for all scientific disciplines in the country. It rema ins perhaps the most important challenge: to ensure that we replenish the c urrent reservoir of human capital in all scientific fields while at the same time continuing to broaden the base of knowledge production in the country through the inclusion of more female and black scholars and academics.

There is also some evidence that Social Science and Humanities scholarship is perceived in some government circ les as essentia lly instrumenta list (refer to the DST 5-Year Strategic Plan). Although Huma nities sc holarship is a pprecia ted, it is not necessarily for its intrinsic ep istemic or intellectual value, but because it complements, augments and adds value to scientific and technological endeavours (e.g. social aspects of technology debates, ethics in business debates, and socio-ethic al aspects of health phenomena). This is a challenge that all scholars in the field have to recognise and reflect in theirtraining and mentoring of the next generation of Humanities sc holars and academics.

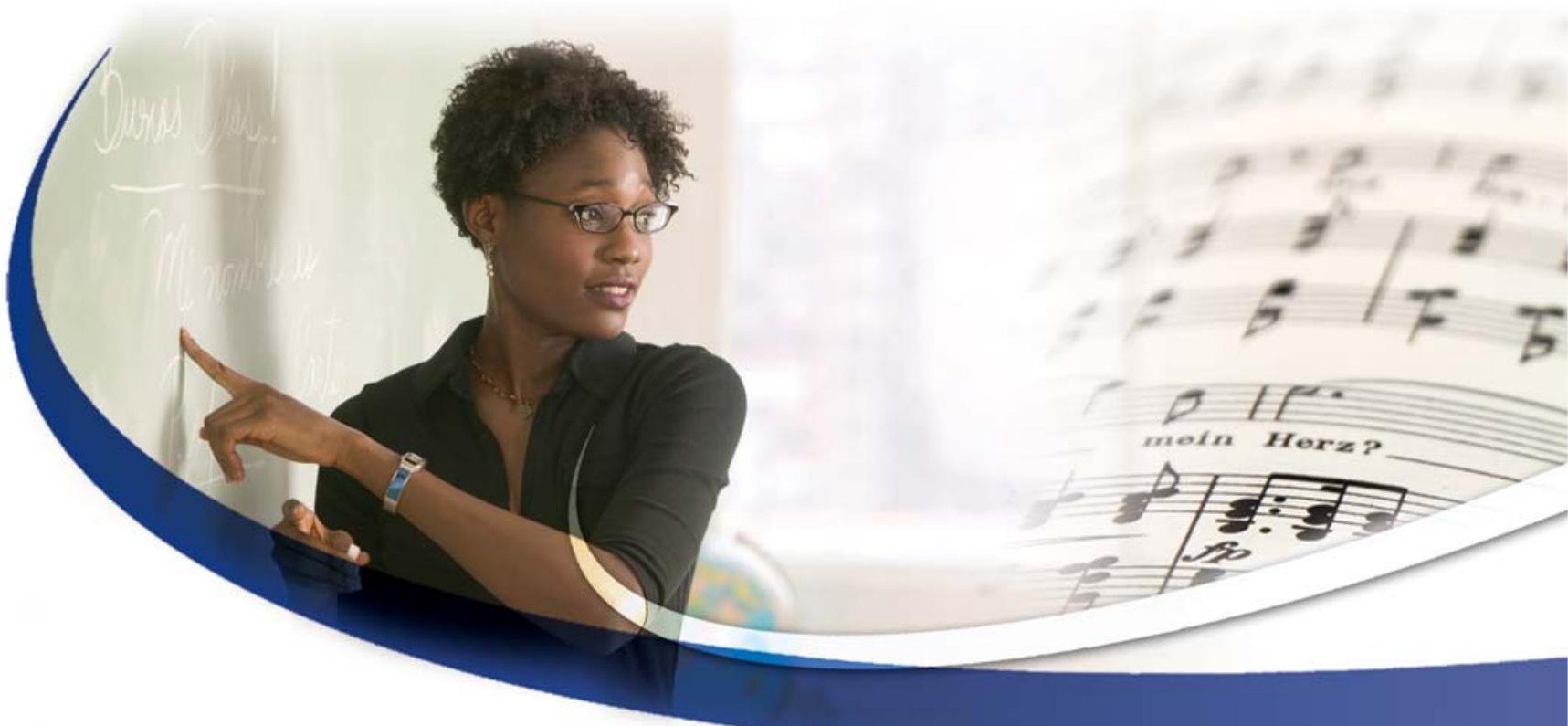




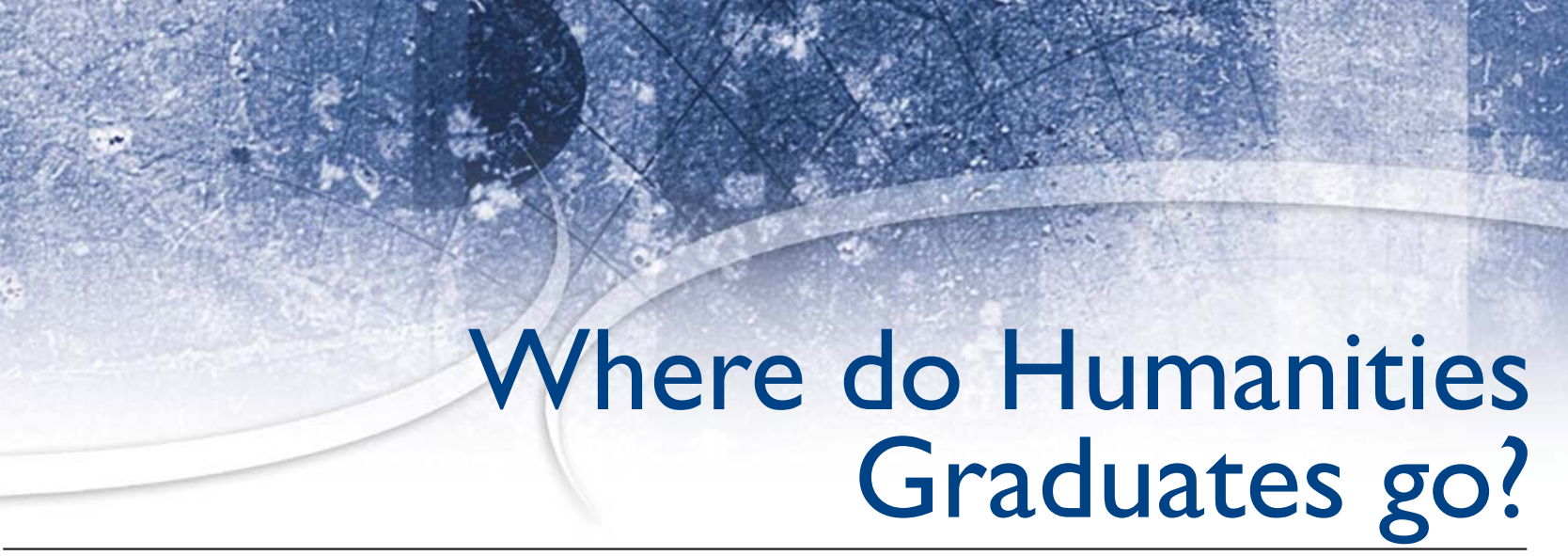

This chapter addresses two major questions:

- Where are ourgraduates now and what a re they doing?

- How are they doing and what are their experiences?

The a nswer to the first question a ppea rs rela tively stra ig htforwa rd: Most a re working (84\%) and, of these, most are formally employed on a permanent full-time basis in the public sector. However, there are fairly significant numbers who are self-employed and creating their own employment. This latter category of employment requires additional 'unpacking' as to the motivation behind the self-employment. Is it intentional or do Huma nities gradua tes find it more diffic ult to find jobs? Why a re so many more Huma nities graduates working for an employer while at the same time creating their own employment? Is this due to the significantly lower incomes than their c ounterparts from Science fields that lea ds Huma nities gradua tes to augment their inc ome? 
Concems about the relatively high proportion of graduates (partic ula rly Master'sand doctoral graduates) working abroad also need to be addressed. Without an understanding of the reasons for working abroad or the nature of the work, are these justifiable concems? Is higher education not required to prepare students for careers in the global economy?

In answer to the second question, Huma nities graduates appear to be generally happy and satisfied. They report a positive relationship between their completed studies and current employment and consider their academic training to have been relevant. They generally feel that their studies prepared them well for their c urrent jobs, and that their current employment utilises their acquired knowledge and skills. Humanities graduates are therefore as well prepared for a future place of work asothergraduates, and these graduatesare overwhelmingly satiffied with their current employment and feel that their jobs are a realisation of their professional ideals.

However, although the study shows a very positive relationship between academic training and the world of work, there is possibly a need forfurther investigation in terms of preparation for the world of work, particularly at the bachelor's degree level, where a significant proportion of gradua tes indic ated that their studies did not prepare them well for their current employment.

The study found that Humanities graduates perceive a positive and stable relationship between tertiary education and workplace employment. However, such results should be compared with employer perceptions regarding the knowledge, skills and preparedness of their Humanities graduate employees. This would contribute to addressing perceived gaps between employer expectations and HE outc omes.

It would also be interesting to analyse the data from the study further in terms of genderand population groupings, particularly in terms of income, work assignment and intemuption of study.

This study and its findings serve as a nother important step in providing empirical evidence for the relevance of tertiary education. As part of their own a ccountability requirements, ind ividual institutions should perhaps be required to undertake similar tracer studies to get systematic feedback from graduates in order to improve their Huma nities programmes.
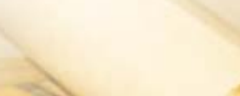


\section{Main Findings}

\section{Finding 1}

There is a crisis in the Humanities reflected in declining student enrolments, falling gra duations, and decreasing govemment funding (in real Rands) within institutions of higher leaming.

\section{Finding 2}

The evolution and administration of govemment policy in the post-apartheid period hassystematic ally benefited Science, Technology, Engineering and Mathematics (the so-called STEM disciplines) to the exclusion and even detriment of the Huma nities disciplines in the country.

\section{Finding 3}

The Humanities within institutions of higher learning is in a state of intellectual stagnation and, singular innovations notwithstanding, has remained in this moribund condition for more than 15 years.

\section{Finding 4}

The evidence on Huma nities graduates show clea rly that virtually all Huma nities gra dua tes are employed, that the vast majority (more than $80 \%$ ) work for an employer, while the rest are selfemployed, and that there is a fairspread of graduate employment across the public and private sectors. 


\section{Finding 5}

The decline of the Humanities has many causes that include govemment policy and funding, institutional choic es and decision-making, sc hool guidance and counselling, and parental and student preferences.

\section{Finding 6}

The weight of scholarship in the Humanities lacks intemational status and standing, with most of the published work appearing in local joumals and most of these local publications in nonaccredited (non-ISI) publication sources.

\section{Finding 7}

The scholarship of the Humanities still strongly reflects the racial inequalities in knowledge production in the national sc ience system, with all but one (Education, at 21\%) of the Huma nities fields falling well below $20 \%$ of total output contributions on the part of black scholars - despite marginal gains over the previous decades.

\section{Finding 8}

The single most important threat to the growth of an intellectually vibrant scholarship in the Humanities is the problem of an ageing academic and research workforce, a factor that must be read alongside the evidence of a dec line in doctoral graduates in the Huma nities fields.

\section{Finding 9}

The low proportion of academic staff with doctorates means that the institutional capacity to reproduce and replace high-level scholars and scholarship in the Humanities will remain compromised into the nearfuture.

\section{Finding 10}

The performance and prospects of the Huma nities varies considerably a cross different field s of study (Theology and Education versus Law and Languages, for example), and this means that a ny interventions will require fine-tuned strategies among these va riousfields rather than a blunt instrument of policy change for the Humanities as a whole. 


\section{Ten Game-breaking Recommendations}

\section{Recommendation 1}

Establish with statutory status a Counc il for the Humanities to advise Govemment on how to improve the statusand standing of the Humanities in South Africa.

\section{Recommendation 2}

Review and refine govemment funding allocations to the Humanities with substantive earmarked funding in critical a reas such as Afric an Languages (the Ministerial investigation underway is a positive sign), Philosophy, History and the Creative and Performing Arts. In this context, the advancement of books by the academy and the funding of books by govemment could signific antly enhance the book as a cultural and human asset in both the scholarly and public mind. One possibility would be to link an award for the best Humanities book every year to the annual Alan Paton Award.

\section{Recommendation 3}

Commit to the development of a govemment white paper on the Humanities, to establish in the public mind and in govemment policy a renewed emphasis on the Humanities, and its full integration into national science policy.

\section{Recommendation 4}

Restructure funding for advanced degrees (doctorates in particular) through national funding agencies, such as the NRF, to enable full-time study for top candidates in the Humanities who make the choice of academic careers.

\section{Recommendation 5}

Accelerate the establishment of prestigious Research Chairs and Centres of Excellence in the Humanities, appointing leading professors of the Humanities with two clear missions: the pursuit of excellence in Huma nities researc $h$ and the build ing of capacity for next-generation Humanities scholars. 


\section{Recommendation 6}

Inaugurate a dedicated National Fund for Humanities Research, to combine earmarked govemment funding with national and intemational private and philanthropic funding that fuels top-qua lity Huma nities resea rch within and outside So uth Afric an universities.

\section{Recommendation 7}

Transform the organisation and design of the Academy of Science of South Afric a (ASSAf) so that a more emphatic statement of its commitment to the Humanities becomes self-evident, e.g. the re-naming of the Academy; the investigation of a second premier academy journal spec ific a lly for the Huma nities; the constitution of 50\% Huma nities appointments to Counc il; and other signalling measures for the only recognised academy in South Africa.

\section{Recommendation 8}

Initiate, through the leadership of the Department of Basic Education, considered measures to boost knowledge of and positive choic esfor the Humanities throughout the 12 years of schooling, including progressive ways of privileging the Arts, History and Languages in the school curric ulum through Grade 12.

\section{Recommendation 9}

Advance the idea of a broad-based Humanities cumic ulum, ideally in an interdisciplinary core study programme for undergraduates, to expose all university students to some study of the Huma nities.

\section{Recommendation 10}

Promote in the broader soc iety the value of the Humanities and Humanities scholarship and practice through prestigious awards that draw national and international attention to the Huma nities among school students, university students, scholars, and intellectuals in the broad. An Annual National Humanities Lecture, to be televised and linked to a National Medal in the Humanities, would do much to signal the importance of the Humanities in the public sphere.
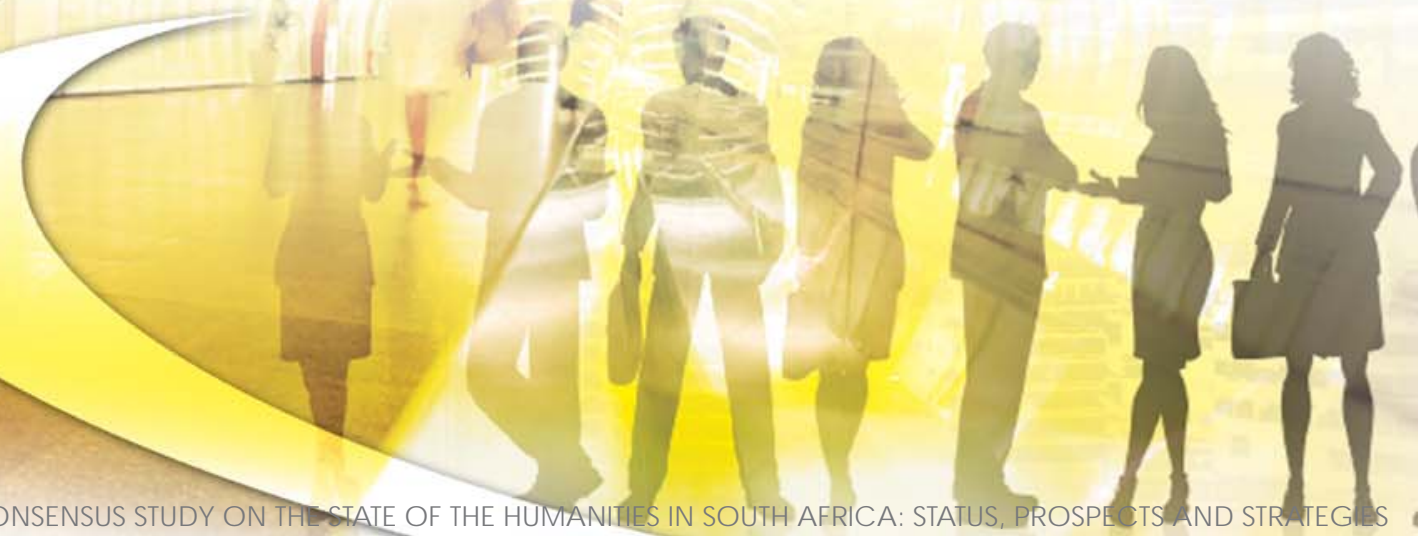
As this is the first-ever report on the Humanities in So uth Africa, although comprehensive, it is by no means complete, and should thus also serve to stimulate debate and further research on a number of important questions which a Study of this nature inevitably ra ises; such as, a mongst others:

- Issues related to the quality of teaching and the quality of the scholarship in the Humanities.

- Questions regarding student and staff numbers and reasons why student numbers are declining.

- The nature of employment of rec ent Humanities graduates.

-What employers want and how they interpret the notion of 'employa bility'.

-Who the potential stakeholders for the Humanities might be.

- The importance of academic in their engagement with public sand whether or how sc holarly work influences soc iety and social change in a ny way (directly or ind irectly).

There is something of a crisis in the Huma nities, but a crisis can generate opportunities to do things differently. That the Humanities are indispensable is beyond argument; but there are unexplored possibilities a bout how the Huma nities can contribute to society and the economy. This challenge should be accepted.

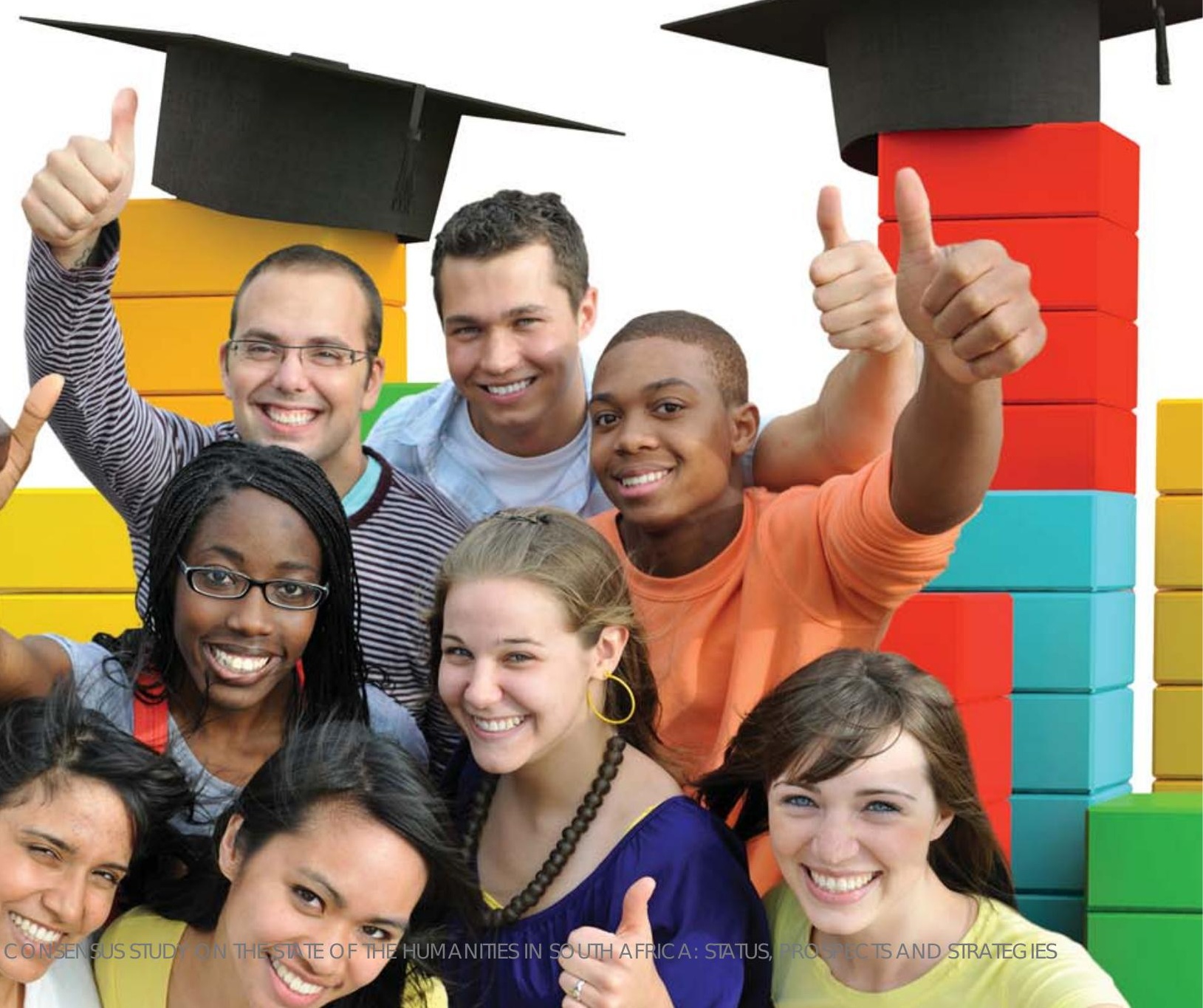




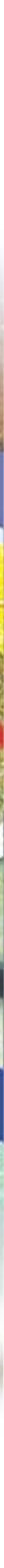


Consensus Study on the State of the Humanities in South Africa: Status, Prospects and Strategies

Academy of Science of South Africa (ASSAf)

Academy of Science of South Africa

Academy of Science of South Africa (ASSAf), (2011). Consensus Study on the State of the

Humanities in South Africa: Status, Prospects and Strategies. [Online] Available at: DOI http://dx.doi.org/10.17159/as http://hdl.handle.net/20.500.11911/33

Downloaded from ASSAf Research Repository, Academy of Science of South Africa (ASSAf) 